\title{
Assessing Urban Forest Structure and Health in Shenyang, China
}

\author{
Zhu Hua Ning, Xing Yuan He, Chang Fu Liu, and Kamran K. Abdollahi
}

\begin{abstract}
This article summarizes the assessment of the urban forest structure and health in central areas of Shenyang, China. Urban forest cover analysis was conducted using aerial photographs, satellite imagery, and a field survey of 282 plots as major study methods. Based on the location, function, and management objectives, the urban forests were classified into five cover types: landscape forests, ecologic forests, road forests, park forests, and commercial forests. Total tree cover in the study area is $7.85 \%$. Most trees and shrubs are in good to very good health and have relatively small diameter at breast height and height. The major tree species are different in urban and suburban areas, which was the result of the natural occurrence of the species and manmade disturbances. Major recommendations for the future management include increasing urban forest cover, especially in the city center, east side, and outskirts; and increasing species diversity and urban forest connectivity.
\end{abstract}

Key Words. Distribution; health condition; species composition; tree cover; urban forest structure.

Over the past 10 to 15 years, urban expansion has been occurring more rapidly than at any time in China. Currently, approximately $41 \%$ of China's people are living in cities, compared with $26 \%$ at the end of the 1980s, and the country is still rapidly urbanizing (Wu et al. 2008). Thus, city greening and urban forestry have become very important issues, because many Chinese cities have air pollution problems. Urban forest is one of the defining features of a city and a region. Proper urban forest structure and health are the cornerstones of urban forest sustainability, because they strongly influence the urban forest function and benefits. Urban forest structure and health assessment is highly important because it provides crucial characteristics of the green infrastructure (Smith et al. 2005). Many urban forest management questions could be quickly and effectively addressed using geospatial methods and tools (Ward and Johnson 2007). The geospatial tools can provide timely and extensive spatial data from which urban forest attributes can be derived such as land cover, forest structure, species composition and condition, heat island effects, and carbon storage. However, the ground survey methods must be used along with the geospatial methods to increase the accuracy of the study results.

To promote urban forestry and to obtain baseline information for better management decisions and practices, an urban forest assessment was conducted in central Shenyang, China. The assessment has many objectives and the objectives related to this article were to establish, for the first time in the history of Shenyang, permanent urban forest assessment plots for the first assessment and future assessments; to assess urban forest structure such as urban forest cover, cover types, species composition, size, location, and distribution; and to assess the overall urban forest health.

\section{METHODOLOGY}

\section{Study Area}

Shenyang is the largest city in northeast China. It is the capitol city and political, economic, and cultural center of Liaoning Province and is among the ten largest cities in China. It is also an important industrial base and a historical city with three UNESCO World Heritage Sites. As the host city of the 2006 International Horticultural Exposition and venue for the soccer matches of the 2008 Beijing Olympic Games, Shenyang has become the focus of worldwide attention. We selected the city of Shenyang for this study because it is representative of largesized cities in China with a noticeable urban forest component.

Shenyang is located in northeast China at $41^{\circ} 47^{\prime} 44^{\prime \prime}$, $123^{\circ} 26^{\prime} 53^{\prime \prime} \mathrm{E}$. It is in the temperate zone and is greatly influenced by monsoons year round with an annual average temperature of $7^{\circ} \mathrm{C}$ to $8^{\circ} \mathrm{C}\left(45^{\circ} \mathrm{F}\right.$ to $\left.46^{\circ} \mathrm{F}\right)$ and precipitation of 510 to $680 \mathrm{~mm}$ (20.4 to 27.2 in). The natural forest soil is brown eluvial with a thick humus layer and high phosphorus and relatively low nitrogen contents. The dominant forest species are Pinus tabuliformis and Quercus mongolia. Pinus tabuliformis is the city tree of Shenyang.

This study targeted the central area of Shenyang (Figure 1), which is comprised of $1,150 \mathrm{~km}^{2}\left(460 \mathrm{mi}^{2}\right)$ and is divided into two sectors, an urban area totaling $455.77 \mathrm{~km}^{2}\left(182.31 \mathrm{mi}^{2}\right)$ and a suburban area totaling $694.24 \mathrm{~km}^{2}\left(277.70 \mathrm{mi}^{2}\right)$. The central area and its two sectors are defined using the existing definition in China. The urban area is classified as the area within the third ring road, a circular loop on the outskirts of the city. The suburban area is classified as the area outside of the third ring road. The term suburban is defined somewhat differently than in the United States. The suburban area in the northeast of China is more rural in nature than suburban areas in the United States, because there are more agricultural lands and small farms than residential or bedroom communities with dense urban vegetation cover. Therefore, it is much like the city's countryside fringe.

\section{Urban Forest Classification}

Various types of built-up areas have different effects on environmental conditions, urban forest structure, and management objectives. Thus, we should not treat urban areas as homogeneous areas by combining all anthropogenic factors into one 


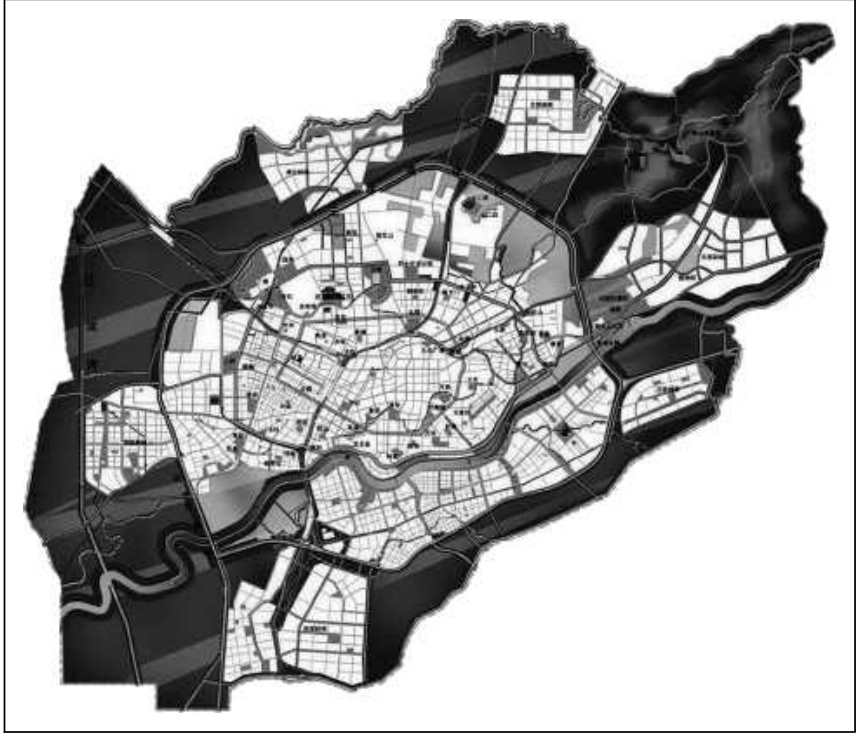

Figure 1. Map of the study area: central Shenyang.

aggregated variable. Instead, the urban matrix should be categorized in subsystems because it is multidimensional and highly variable across space (Godefroid and Koedam 2007).

Therefore, this assessment classified the urban forests in the study area into five types based on their function, location, land use type, distribution, benefits provided, and management objectives. The five types are:

1. Landscape forest (L): trees located near and around buildings for landscape purposes, including schoolyards, campuses, hospitals, commercial and business districts, industrial areas, and residential areas. The major functions are to beautify and improve people's living and working environments.

2. Road forest $(\mathrm{R})$ : trees along railroads, highways, boulevards, roads, streets, and intersections and by bridges. The major functions are to protect the road, direct and regulate traffic, block traffic noise, and absorb traffic-related pollution.

3. Park forest $(\mathrm{P})$ : trees in public parks, forest parks, historic places, and scenic areas. The major functions are to provide recreation opportunities, sightseeing and vacation spots, locations for education and cultural activities, and to improve the environment.

4. Ecologic forest (E): trees and forests at the outskirts of the city planted as wind breaks, sand stabilizers, and pollution/ noise reducers; by water bodies such as rivers, dams, and lakes to protect watersheds and improve water quality; between residential areas and industries to block pollution and noise; by levees to prevent flooding; and on slopes or adverse soils to prevent soil erosion.

5. Commercial forest $(C)$ : trees in nurseries, orchards, plantations, and woodlands for commercial purposes. The major functions are to provide seedlings and saplings for urban greening and reforestation, for fruit production, and for nontraditional forest products.

\section{Urban Forest Cover Analysis}

Study methods were derived from the urban forestry studies in the United States by Nowak (1992, 1994), McPherson et al.
(1997), Miller (1997), Dwyer et al. (2000), and Nowak et al. (2002). Two major study methods were used, urban forest cover analysis and ground survey. Panchromatic aerial photographs (1:15,000 and 1:1,000) taken during the August 2001 flyover at a flying height of $1,500 \mathrm{~m}(4,950 \mathrm{ft})$ specifically made for this particular project were used for the urban forest cover analysis. Landsat TM5 satellite photographs from August 2001 were also used along with 1997 Landsat TM5 satellite photographs for comparison. The aerial photographs were scanned at $600 \mathrm{dpi}$ and digitized manually at $1 \mathrm{~m}(3.3 \mathrm{ft})$ resolution to analyze the urban forest cover by using ArcGIS 8.1 (ESRI, New York, NY). The digitized map identified the five types/categories of urban forest cover.

\section{Field Plot Establishment}

The stratified random field sample plots were mapped and evenly distributed based on the urban forest location, cover type, and size. An eTrex GPS (Garmin, Olathe, KS) unit by Garmin was used in the field to locate the plot sites. The total of 282 plots of three different sizes was established to ensure proper representation and coverage of all urban forest types. A $20 \mathrm{~m} \times 20 \mathrm{~m}$ $(66 \mathrm{ft} \times 66 \mathrm{ft})$ plot size was used in the parks, forest parks, scenic areas, and suburban areas, because the forests in these areas were relatively dense, resembled the naturally occurring forests, and were distributed in relatively large patches. A $40 \mathrm{~m} \times 40 \mathrm{~m}$ $(132 \mathrm{ft} \times 132 \mathrm{ft})$ plot size was used in areas such as schoolyards, campuses, business districts, and residential areas, because trees were scattered, separated by buildings, and not distributed in large patches. A $20 \mathrm{~m} \times 80 \mathrm{~m}(66 \mathrm{ft} \times 264 \mathrm{ft})$ plot size was used along railroads, highways, boulevards, and roads, because trees are distributed along the roads; therefore, the plots were rectangular.

\section{Field Survey Data Collection}

Field survey data were collected from each plot and every tree and shrub in the plot. Data collected included plot number, date, location, land use type, species name, number of trees per species, tree diameter at breast height (dbh), and tree and shrub height. Tree dbh measurements were categorized into six classes: 0 to $10 \mathrm{~cm}$ ( 0 to 4 in), 10 to $20 \mathrm{~cm}$ (4 to 8 in), 20 to $30 \mathrm{~cm}$ (8 to $12 \mathrm{in}$ ), 30 to $40 \mathrm{~cm}$ (12 to $16 \mathrm{in}$ ), 40 to $50 \mathrm{~cm}$ (16 to $20 \mathrm{in}$ ), and larger than $50 \mathrm{~cm}$ (20 in). Height measurements were classified into five classes: shorter than $3 \mathrm{~m}(9.9 \mathrm{ft}), 3$ to $5 \mathrm{~m}(9.9$ to $16.5 \mathrm{ft}$ ), 5 to $10 \mathrm{~m}$ ( 16.5 to $33 \mathrm{ft}$ ), 10 to $15 \mathrm{~m}$ (33 to $49.5 \mathrm{ft}$ ), and taller than $15 \mathrm{~m}(49.5 \mathrm{ft})$.

\section{Health Condition Assessment}

Tree and shrub health condition data were collected during the field survey. Based on the tree condition assessment methods by the Council of Tree and Landscape Appraisers (2000), tree health was classified into five condition classes, which are 0 , dead/dying; 1, poor/decline; 2, fair/average; 3 , good/very good; and 4 , excellent.

\section{Data Analysis}

Field data were entered into the computer according to the urban and suburban sectors and five major forest cover types. Diameter, height, and health condition distributions of urban and suburban trees and shrubs were obtained by assigning trees/shrubs into respective classes that are described in the previous two sections. Average diameter, height, and health condition index of 
trees/shrubs by urban forest types were obtained by averaging all trees/shrubs in all plots by urban forest types. Species composition was obtained by counting the numbers of species found in all plots. Species frequency was obtained by calculating the percentage of a particular species within the entire population.

\section{RESULTS AND DISCUSSION Urban Forest Cover and Distribution}

The forest cover in the urban area is $8.32 \%$ and occupies roughly $37.92 \mathrm{~km}^{2}\left(15.17 \mathrm{mi}^{2}\right)$ with landscape forest and ecologic forest making up 63\% of the total cover (Figure 2A). Study results showed that Shenyang shares a problem common in big cities in the world, which is the low tree canopy cover in the center of the city. Analysis of the landscape forest distribution indicated that some landscape forests are in a relatively small patch distribution pattern (Figure 3A). For example, there are 389 patches that exceed $5,000 \mathrm{~m}^{2}\left(54,000 \mathrm{ft}^{2}\right)$ and 821 patches that exceed $3,000 \mathrm{~m}^{2}\left(32,400 \mathrm{ft}^{2}\right)$. These results reflect the history of patchstyle tree planting, which set a good example for future urban forest planting and management.

The ideal distribution of road forests is that trees should be distributed along all roads. However, the assessment results indicated that there are many "lonely roads" without trees along the sides (Figure 3B). There are many reasons for this problem. Trees planted along the road have a very low survival rate as a result of the adverse growing conditions caused by poor soil, pollution, and heavy traffic. Because the demand for personally owned vehicles and commercial traffic flow increased, the roads were often widened and the trees that once lined the roads were removed. Although some trees were replaced, the decreased planting space and the lack of manpower and proper care eventually resulted in tree mortality. Some trees that were not removed had the road paved over their roots and they had a difficult time developing properly and subsequently died years later.

Centering around the historical site called North Tomb or Beiling Park, a UNESCO World Heritage Site, where the Second Emperor of Qing Dynasty is buried in the northern part of the city, there are patch distributions of park forests and ecologic forests with some of the patches connected by forest corridors (Figure 3C-D). Along the Hun River and the city's South Canal in the southern part of the city, large patches of park forests and ecologic forests are also distributed and connected by waterways functioning as corridors. The urban forests in the southeast part of the city and close to the outskirts of the city are distributed in smaller and more scattered patches and sometimes with no connecting corridors between the patches.

The distribution of the commercial forests is very low in the urban area (Figure 3E). There is a need to increase tree nurseries in the outskirts of the city to supply saplings and transplant stocks to meet the demand of increasing urban greening efforts.

The forest cover in the suburban area is $7.54 \%$ and occupies roughly $52.35 \mathrm{~km}^{2}\left(20.94 \mathrm{mi}^{2}\right)$. It is mainly distributed in the east and northeast region (Figure 2B) with large patches and a high density of trees and shrubs in the forest parks, scenic areas, and plantations. This distribution pattern resembled the natural forest distribution.

\section{Tree Species Composition}

There are a total of 1,234,132 trees of 87 species in the urban area with Populus spp., Ulmus pumila, and Salix spp. as the three

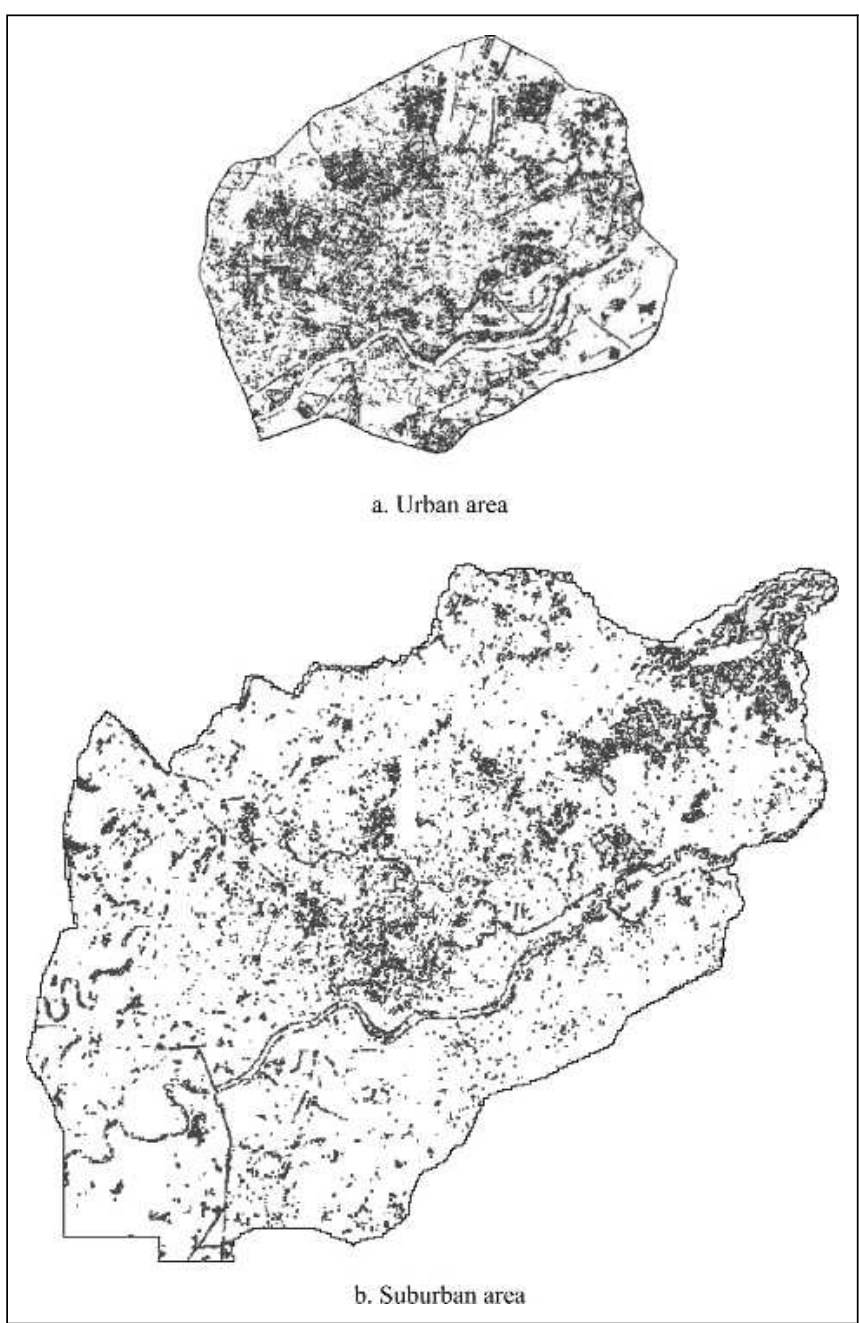

Figure 2. Urban forest distribution (shaded areas) in urban and suburban areas.

most common species (Table 1). The suburban area has 4,601,630 trees of 33 species dominated by Pinus tabuliformis, Quercus Mongolia, and Cotoneaster pinnatifida. Compared with the urban area, the number of trees in the suburban area is $73 \%$ higher and the number of species is $62 \%$ lower. The three major tree species between urban and suburban areas are strikingly different. The common species in the urban area are the results of urban greening and tree planting. The occurrence and wide distribution of the three major species in the suburban area are the remnants of the natural forests and demonstrate the influence of the natural distribution and manmade disturbances. Pinus tabuliformis is a dominant and common naturally occurring species. As a result of population increases and the high demand for shelter and food, some pine forests were cut down and the forest lands were converted to suburban and agriculture lands. Quercus mongolia is a common natural pioneer species after the local climax community was destroyed and $C$. pinnatifida is a major companion species in nature in this area.

\section{Tree Size}

Most trees in the urban area are relatively small with an average $\mathrm{dbh}$ of $20.55 \mathrm{~cm}$ (8.22 in). More than $60 \%$ of the trees are less 


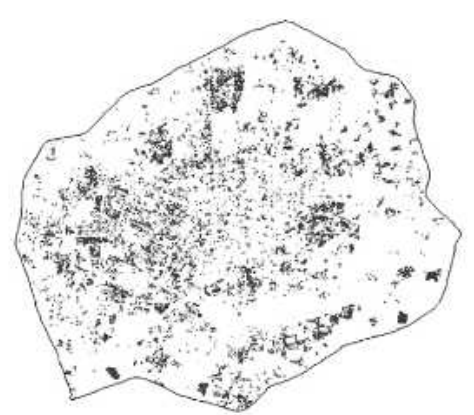

a. Landscape forests: $12.20 \mathrm{~km}^{2}\left(4.88 \mathrm{mi}^{2}\right)$

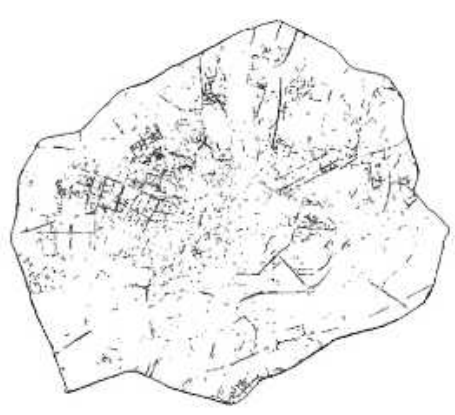

b. Road forests: $6.54 \mathrm{~km}^{2}\left(2.62 \mathrm{mi}^{2}\right)$

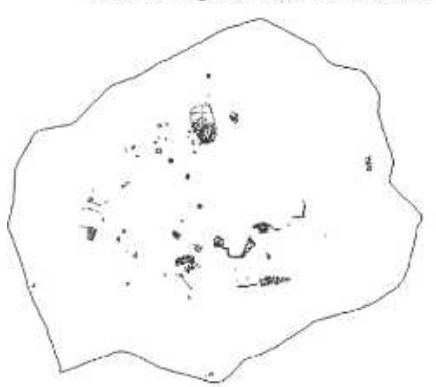

c. Park forests: $5.69 \mathrm{~km}^{2}\left(2.28 \mathrm{mi}^{2}\right)$
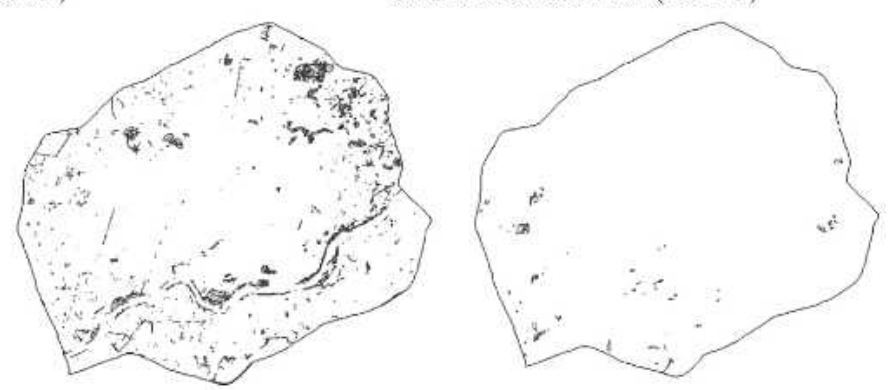

d. Ecological forests: $11.98 \mathrm{~km}^{2}\left(4.79 \mathrm{mi}^{2}\right)$ c. Commercial forests: $1.51 \mathrm{~km}^{2}\left(0.60 \mathrm{mi}^{2}\right)$

Figure 3. Distribution and cover area of different types of urban forests (shaded areas) in the urban area.

than $20 \mathrm{~cm}$ (8 in) in diameter (Figure 4A). Among different forest types, the road trees are more homogeneous in size than other types because of the selection of relatively large tree species when they were planted (Figure 5). The ecologic trees usually grow in a relatively natural setting with some natural regeneration, which resulted in the age difference and created a mix of large and small trees. The landscape trees are more diverse in size compared with other types as a result of the use of different landscape materials. Commercial trees have a relatively even dbh distribution and species composition. The reason that the

Table 1. Shenyang's urban forest major species composition.

\begin{tabular}{lclc}
\hline \multicolumn{4}{c}{ Major tree species } \\
\hline Urban & Percentage & Suburban & Percentage \\
\hline Populus spp. & 15.5 & Pinus tabuliformis & 14.36 \\
Ulmus pumila & 11.5 & Quercus Mongolia & 11.80 \\
Salix spp. & 9.0 & Cotoneaster pinnatifida & 10.26 \\
Robinia pseudoacacia & 8.2 & Ulmus pumila & 6.15 \\
Pinus tabuliformis & 5.8 & Populus spp. & 5.13 \\
Sabina chinensis & 6.2 & Larix Japonica & 4.62 \\
Prunus spp. & 4.5 & Salix spp. & 3.59 \\
& & & \\
& Major shrub species & Percentage \\
\hline Urban & Percentage & Suburban & 27.78 \\
\hline Syringa oblate & 17.8 & Corylus spp. & 18.52 \\
Prunus triloba & 17.8 & Lonicera maackii & 5.56 \\
Ligustrum obtusifolium & 14.0 & Sambucus williamsii \\
Lonicera spp. & 6.0 & Prunus verecunda & 5.56 \\
Rosa xanthina & 4.7 & Ligustrum obtusifolium & 5.56 \\
Spiraea thunbergii & 3.8 & Rosa rugosa & 3.70 \\
Acer ginnala & 3.8 & Syringa spp. & 3.70 \\
Forsythia suspense & 3.0 & Euonymus spp. & 3.70 \\
\hline
\end{tabular}

park trees share the smallest dbh is that in recent years, China began to intensify its greening efforts, which led to many newly planted small trees.

Most trees in the urban area are relatively short, with $65 \%$ less

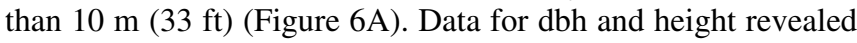
that most of the urban trees are relatively young and in the stage of growth and development. Among all tree types, the ecologic trees are the tallest (Figure 7). Their leading position is the result of high forest density and the competition for light. The road trees are more evenly aged large trees with a relatively even height. The landscape trees and park trees are unevenly aged and some of them were planted very recently in the newly developed districts and greenspaces, which resulted in an uneven height distribution and a smaller average. The commercial trees often include trees in orchards that are pruned to be short for fruit production purposes. Others are in nurseries of young transplantable stock therefore yield the lowest average height.

Compared with the trees in the urban area, the trees in the suburbs are even smaller; more than $76 \%$ are less than $20 \mathrm{~cm}$ ( 8 in) in diameter (Figure 4B). Most trees are either ecologic trees or park trees (Figure 5). The greening efforts did not start in the suburbs as early as in the urban area. Most trees in the suburbs

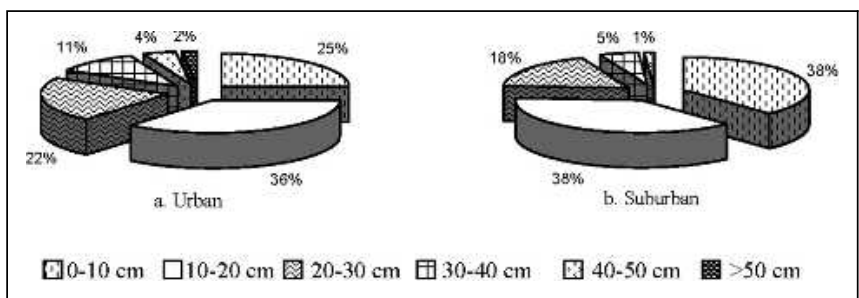

Figure 4. Diameter at breast height distribution of trees in urban and suburban areas. 


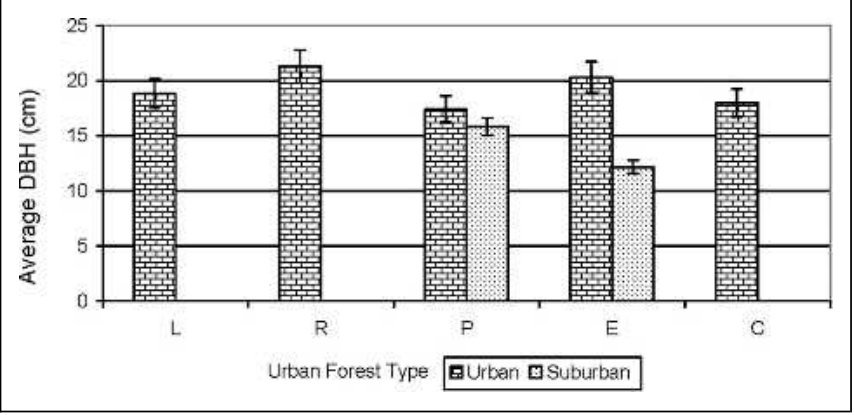

Figure 5. Average diameter at breast height of different types of urban forests in urban and suburban areas. $L$ = landscape forests; $R$ = road forest; $P$ = park forest; $E$ = ecologic forest; $C=$ commercial forest.

were planted in the 1950s and 1960s when there was a massive effort of tree planting by the Chinese government.

Compared with the urban area, the trees in the suburbs are

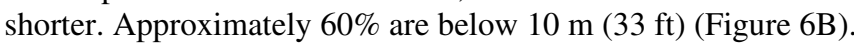
The average height for the ecologic trees is shorter than those in the urban area (Figure 7). The difference could be caused by the species composition difference between urban and suburban. In the suburbs, most ecologic trees are P. tabubliformis, but in the urban area, there are more Populus spp. and Salix spp. planted. Compared with the pines, these broadleaf species are fastgrowing species and yield a higher average height. However, the average height for the park trees is similar to that in the urban area.

\section{Tree Health Condition}

Trees in the urban area are in relatively good health (Figure 8A). Analysis of the health condition by urban forest types showed that the healthiest are the park trees (Figure 9). Because public parks, forest parks, historic places, and scenic areas are the focal points of urban greening in China, there are relatively larger planting spaces and more refined government-funded manage-

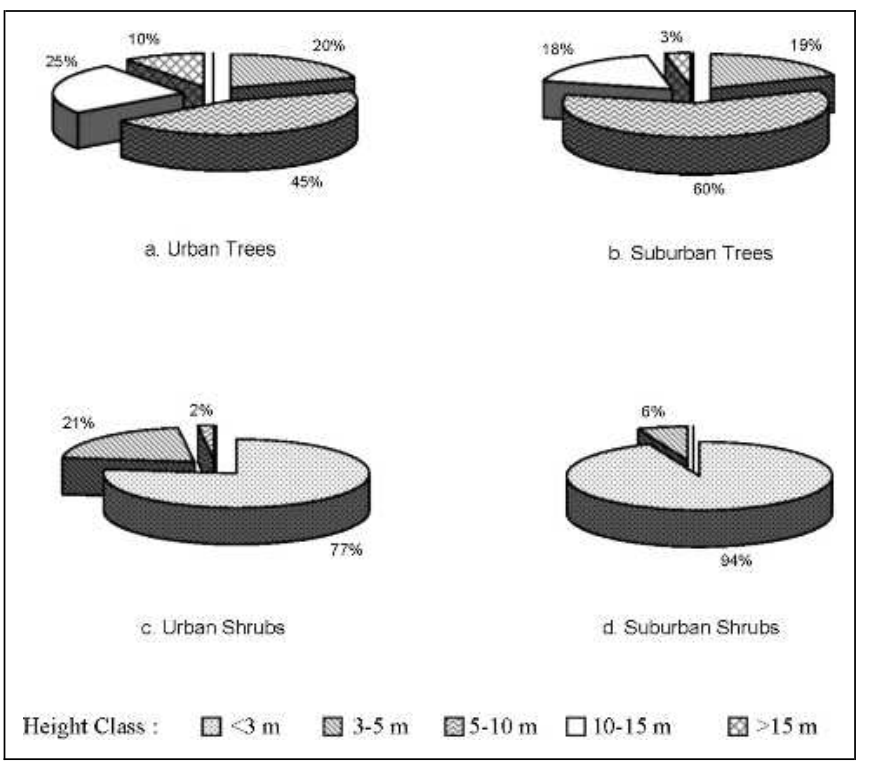

Figure 6. Height distribution of the trees and shrubs.

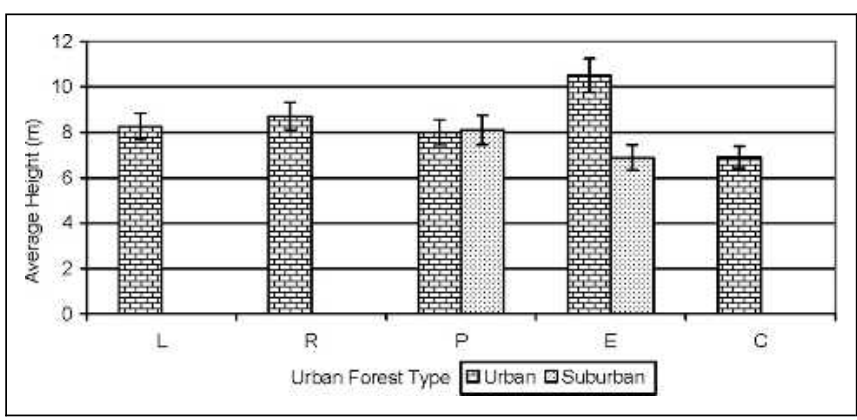

Figure 7. Average tree height of different types of urban forests. $L$ = landscape forests; $R=$ road forest; $P$ = park forest; $E$ = ecologic forest; $C=$ commercial forest.

ment, which yielded the best tree health condition among the five urban forest types. The commercial trees are usually grown in good soil and well maintained by the companies and business owners; therefore, the health conditions are similar to those of the park trees. The landscape trees are not centrally managed because they belong to different entities with different ownerships and have a scattered distribution. Some entities/owners provided better care than others. Therefore, the average health index is slightly lower than that of the park trees and the commercial trees. As a result of construction-related stresses and severe environmental pollution caused by traffic, the road trees have a low average health index. The ecologic trees have the lowest average health index among all five types. Field surveys found that these trees grow in relatively high density with little or no management or maintenance. Competition and neglect have made these trees fall into a lower average.

The tree health condition in suburban areas is similar to that in the urban area (Figure 8B). Compared with the urban area, the park trees' health condition index is slightly lower and the ecologic trees' health index is slightly higher (Figure 9). This may be because the park trees in the urban area are better managed and maintained by the government agencies than in the suburbs, and the ecologic trees in the urban area may suffer from more manmade stresses than in the suburbs.

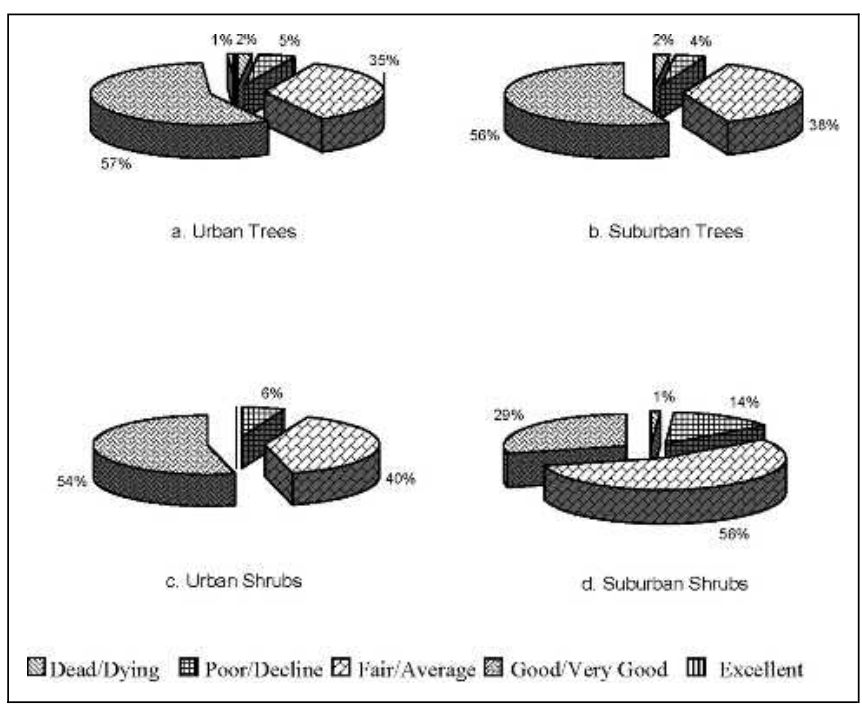

Figure 8. Urban forest health condition. 


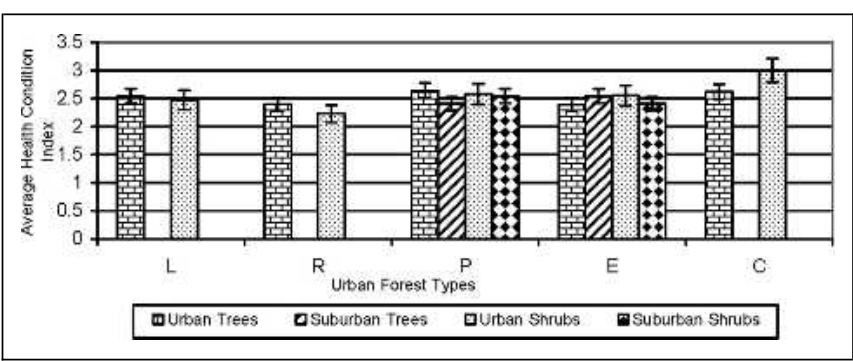

Figure 9. Health condition of different types of urban forests. $L=$ landscape forests; $R=$ road forest; $P$ = park forest; $\mathrm{E}=$ ecologic forest; $\mathrm{C}=$ commercial forest.

\section{Shrub Species Composition, Size, and Health Condition}

There are a total of 232,548 shrubs of 39 species in the urban area; most common shrub species are ranked by frequency in Table 1. Seventy-seven percent of the shrubs are less than $3 \mathrm{~m}$ $(10 \mathrm{ft})$ tall (Figure 6C), and ninety-four percent are in good health condition (Figure 8C). Compared among urban forest types, the average health condition index (Figure 9) of the shrubs along roads is the lowest, and the shrubs in the commercial nurseries and orchards are the highest followed by shrubs in public parks, forest parks, scenic areas, and historical places. In the suburban area, shrubs are found in the park forests and ecologic forests. There are a total of 706,617 shrubs of 16 species in the suburban area. Compared with the urban area, the number of shrubs in the suburbs is $67 \%$ higher and the number of species is $59 \%$ lower. Compared with the urban area, the major shrub species are different, the size is smaller, and the health condition is similar (Table 1; Figures 6D, 8D, and 9).

\section{CONCLUSIONS}

We hope that this study demonstrates the feasibility and usefulness of urban forest assessment and monitoring in China. Results presented in this article only document baseline urban forest structure and health conditions. The refinement of the methods used in this study will result in a data collection protocol that can be used to assess and monitor urban trees and detect changes in their condition, status, and health.

Urban vegetation management in China places major emphasis on the absolute quantity of greenspace such as total area of urban vegetation, total canopy cover, and per capita vegetation cover and overlooks other structural attributes of urban vegetation as indicators of improvement in urban greening plans (Yang et al. 2008). To establish a better urban forest structure and maximize the ecologic benefits, Shenyang, through its urban planning and greening efforts, should increase its urban forest cover by enhancing the tree planting in the city center, southeast and outskirts of the city, in the newly developed residential areas, along roads, and in the parks. The city's North Canal can be used as a corridor to connect the urban forest from the east to the west. The connectivity of the urban forest patches in the urban landscape may be critical for maintaining the species population and diversity (Zipperer et al. 2000).

Species diversity should be one of the priorities in future planting and greening efforts. Assessment showed that species such as Tilia mandshurica, Sophora japonica, Koelreuteria bipinnata, Pinus armandi, Acer truncatum, Tilia amurensis, Celtis bungeana, and Ginkgo biloba grow very well in Shenyang and can be used in future planting to increase diversity and for their high aesthetic values.

Size distribution of the trees in Shenyang is very similar to the results presented by Yang et al. (2005) of the urban forest structure study in Beijing. The lack of large trees presents a problem for proper carbon dioxide and pollution sequestration, carbon storage, and other ecologic benefits that larger trees can provide (Nowak and Crane 2002; Nowak et al. 2002). Most trees and shrubs are in good to very good health condition and have relatively small dbh and height.

There are more species in the urban areas than in the suburbs and the major tree species composition is very different. The species occurrence and distribution in both urban and suburban areas are strongly influenced by the species' natural occurrences and manmade disturbances. Compared with the suburbs, the species in the urban area are more introduced than native. This trend affects the suburban species composition as well. More native species are being replaced by the introduced species. As Shenyang expands its urban area as a result of urban development, it is anticipated that the species composition will change drastically in the suburbs.

In the suburbs, massive tree planting efforts for the purpose of establishing forest plantations have both positive and negative outcomes. It is anticipated that these forest plantations will provide economic and ecologic benefits. However, the use of only a few species such as Pinus tabuliformis and Robinia pseudoacacia may result in an even aged and nearly single species plantation that is not ecologically sound.

Acknowledgments. The results presented in this article are from a portion of a project entitled Urban Forest Ecology funded by the Chinese Academy of Sciences (CAS) with project number C99AD-BR010502 and project director Dr. Zhu H. Ning. The research is also supported by the Foundation of Knowledge Innovation Program of the Chinese Academy of Sciences with project number KZCX3-SW-43 and project director Dr. Zhu H. Ning. Special thanks go to the project team members at the CAS Institute for Applied Ecology, Shenyang, China, under the leadership of Director Dr. Xing Y. He. Special credits for the field study, data collection, and analysis for this article go to Dr. Chang F. Liu.

\section{LITERATURE CITED}

Council of Tree and Landscape Appraisers. 2000. Guide for Plant Appraisal. 9th Edition. International Society of Arboriculture, Champaign, IL.

Dwyer, J.F., D.J. Nowak, M.H. Noble, and S.M. Sisinni. 2000. Connecting People With Ecosystems in the 21 Century: An Assessment of Our Nation's Urban Forests. General Technical Report PNWGTR-490. USDA Forest Service, Pacific Northwest Research Station, Portland, OR. 483 pp.

Godefroid, S., and N. Koedam. 2007. Urban plant species patterns are highly driven by density and function of built-up areas. Landscape Ecology 22:1227-1239.

McPherson, E.G., D.J. Nowak, G. Heisler, S. Grimmond, C. Souch, R. Grant, and R. Rowntree. 1997. Quantifying urban forest structure, function, and value: The Chicago urban forest climate project. Urban Ecosystems 1:49-61.

Miller, R.W. 1997. Urban Forestry: Planning and Managing Urban Green Spaces. Prentice Hall, Upper Saddle River, NJ.

Nowak, D.J. 1992. Remote sensing and urban forestry. Proceedings of the Society of American Foresters 1992 National Convention.

1994. Understanding the structure of urban forests. Journal of Forestry 92:42-46. 
Nowak, D.J., and D.E. Crane. 2002. Carbon storage and sequestration by urban trees in the USA. Environmental Pollution 116:381-389.

Nowak, D.J., J.C. Stevens, S.M. Sisinni, and C.J. Cules. 2002. Effects of urban tree management and species selection on atmospheric carbon dioxide. Journal of Arboriculture 28:113-122.

Smith, P.D., M. Merritt, D. Nowak, and D. Hitchcock. 2005. Houston's Regional Forest: Structure, Function, and Values. US Forest Service and Texas Forest Service, College Station, TX.

Ward, K.T., and G.R. Johnson. 2007. Geospatial methods provide timely and comprehensive urban forest information. Urban Forestry and Urban Greening 6:15-22.

Wu, Z., C. Huang, W. Wu, and S. Zhang. 2008. Urban forest structure in Hefei, China, pp. 279-292. In: Ecology, Planning, and Management of Urban Forests, International Perspectives. Carreiro, M.M., Y.C. Song, and J. Wu (Eds.). Springer, New York, NY.

Yang, J., P. Gong, and J. Zhou. 2008. Spatial and temporal change of urban vegetation distribution in Beijing, pp. 346-356. In: Ecology, Planning, and Management of Urban Forests, International Perspectives. Carreiro, M.M., Y.C. Song, and J. Wu (Eds.). Springer, New York, NY

Yang, J., J. McBride, J. Zhou, and Z. Sun. 2005. The urban forest in Beijing and its role in air pollution reduction. Urban Forestry and Urban Greening 3:65-78.

Zipperer, W., J. Wu, R. Pouyat, and S.T.A. Pickett. 2000. The application of the ecological principles to urban and urbanizing landscapes. Ecological Applications 10:685-688.

Zhu Hua Ning

Southern University-Urban Forestry Program, SU Ag Center

PO Box 11686 SUBR

Baton Rouge, LA 70813, U.S.

zhu_ning@subr.edu

\section{Xing Yuan He}

Institute for Applied Ecology

Chinese Academy of Sciences

Shengyang, Liaoning, China

Chang Fu Liu

Shenyang Agriculture University

Shengyang, Liaoning, China

Kamran K. Abdollahi

Southern University-Urban Forestry Program, SU Ag Center

PO Box 11686 SUBR

Baton Rouge, LA 70813, U.S.
Résumé. Cet article fait un sommaire des évaluations de la structure et de la santé de la forêt urbaine dans les régions centrales du Shenyang en Chine. L'analyse du couvert de la forêt urbaine a été menée au moyen de photos aériennes, d'imagerie satellite et de relevés au sein de 282 unités d'échantillonnage sur le terrain tout comme avec des méthodes majeures d'étude. En se basant sur des objectifs de localisation, de fonction et de gestion, les forêts urbaines ont été classifiées en cinq types de couvert: forêts aménagées, forêts écologiques, forêts de routes, forêts de parcs et forêts commerciales. Le couvert arboré total de cette étude s'est élevé à $7,85 \%$. La plupart des arbres et des arbustes sont en bonne condition de santé et sont de relativement petits diamètres au D.H.P. ainsi que de faible hauteur. Les espèces dominantes sont différentes en milieu urbain par rapport en banlieue, ce qui était le résultat de la fréquence naturelle des espèces et des perturbations causées par la main de l'homme. Les recommandations majeures pour la gestion future incluent l'accroissement du couvert de la forêt urbaine-particulièrement dans le centre de la ville, du côté est et en périphérie-ainsi l'augmentation de la diversité en espèces et de la connectivité ville/forêt.

Zusammenfassung. Dieser Artikel fasst die Untersuchung der urbanen Forststruktur und -gesundheit in den zentralen Regionen von Shenyang, China zusammen. Die Analyse der urbanen Forstlandschaft wurde hauptsächlich durch Luftbilder, Satellitenbilder und Feldbesichtigung von 282 Flächen durchgeführt. Die urbanen Forste wurden anhand von Örtlichkeit, Funktion und Managementziele in fünf Typen unterteilt: landschaftliche Wälder, ökologische Wälder, Strassenbegleitende Wälder, Parks und kommerzielle Wälder. Die totale Baumbedeckung in der untersuchten Region betrug 7,85\%. Die meisten Bäume und Sträucher sind in gutem bis sehr gutem Zustand und haben einen relativ schmalen Durchmesser und Höhe. Die vorkommenden Baumarten unterscheiden sich in urbanen und suburbanen Regionen, was auf natürlicher Artenkonkurrenz und menschlichem Einfluß beruht. Die hauptsächlichen Empfehlungen für das zukünftige Management schließen eine auszudehnende urbane Forstfläche, besonders in den Stadtzentren, der Ostseite und den Randbezirken, ein, und eine größere Artenvielfalt sowie eine Verbindung der Waldflächen

Resumen. Este artículo resume la evaluación de la estructura forestal urbana y salud en áreas centrales de Shenyang, China. El análisis de cobertura fue dirigido usando fotografías aéreas, imágenes de satélite, y datos de 282 parcelas como métodos principales de estudio. Con base en la localidad, función y objetivos de manejo, los bosques urbanos fueron clasificados en cinco tipos de cobertura: bosques escénicos, bosques ecológicos, bosques de caminos, bosques de parques y bosques comerciales. El total de cobertura en el área de estudio es $7.85 \%$. La mayoría de árboles y arbustos están en buenas a muy buenas condiciones de salud y tienen relativamente alturas y diámetros pequeños a la altura del pecho. Las principales especies de árboles son diferentes en áreas urbanas y suburbanas, lo cual fue el resultado de la ocurrencia de especies y disturbios antropogénicos. Las recomendaciones principales para el manejo futuro incluyen el incremento de la cobertura del bosque urbano, especialmente en el centro de la ciudad, lado este, y periferias; y el incremento de diversidad de especies y conectividad del bosque urbano. 